Perspectives of the ENP, and Perspectives of the EU: Neighbourhood, Enlargement, and Ur Chilosi, Alberto

Aussenwirtschaft; Sep 2009; 64, 3; ABI/INFORM Collection pg. 253

\title{
Perspectives of the ENP, and Perspectives of the EU: Neighbourhood, Enlargement, and Unanimity
}

\author{
Alberto Chilosi* \\ Department of Economics-University of Pisa
}

\begin{abstract}
The paper considers the state of the ENP policy in the framework of the present institutional impasse of the EU. Even if the Lisbon Treaty enters in force, an acceptable functioning of the EU with 27 members can hardly be compatible with the permanence of the unanimity vote for the most important decisions, such as budgetary issues or enlargement. Further enlargement under these circumstances can be seen both as difficult and ill-advisable: a higher number of members (and more heterogeneous) increases the probability that the requirement of unanimity may lead to disruptive strategic behavior. Thus enlargement of the market, and legal approximation, can best take place, realistically speaking, in the framework of ENP. At the same time the assistance to recognized prospective members, who probably will not be able to enter in the foreseeable future, could well perform a role not too different from that of ENP, amounting substantially to a kind of ENP in disguise. In both cases we have the use of the typical instruments for the preparation of enlargement, but with some different stated objectives, and a different framework for financial assistance. So long as enlargement seems concretely possible the prospect of membership may continue to have additional incentive effects. The momentum for reform may however be lost if eventually the process is seen as never-ending. Some greater approximation to membership status can be provided by an extended ENP policy, but it seems highly unlikely that the internal dynamics of the EU will allow even the most compliant of the neighbours to enjoy the same economic advantages of actual membership, as the paradigm of "everything but institutions" would imply.
\end{abstract}

JEL classification: $\mathrm{F} 15$

Keywords: $\quad$ European Neighbourhood Policy, EU Enlargement, European Union

\section{Wider Europe}

In the perspective of the 2004 enlargement, the Luxemburg General Affairs Council of 15 April 2002 considered for the first time the issue of EU's relations with the future new Eastern neighbours, under the heading "Wider Europe". On the instigation of that Council Chris Patten and Javier Solana prepared a memorandum, again under the heading "Wider Europe", presented to the Brussels General Affairs Council on 30 September 2002, where the basic principles of what was to become the EU Neighbourhood Policy were laid. The issue of the relationship to the new Eastern neighbours was placed in the framework of the wider issue of the relationship of Europe with its Eastern, South-Eastern, and Southern neighbours:

* Thanks are due to Susan Senior Nello for very helpful comments and suggestions. The usual caveat applies. 
"The pace and scope of this process will have to be flexible - there can be no one-size-fits-all approach. The starting point should be that relations with all our neighbours should be based on a shared set of political and economic values. Building on this, we should aim towards regional stability and co-operation, closer trade links and approximation and/or harmonisation of legalisation [sic!] and progressive extension of all relevant EU policies. Looking to the medium and longer term, we could foresee a gradually evolving framework for an economic and political space surrounding the Union, which would nevertheless stop short of full membership or creating shared institutions. Building on existing instruments and relations, this approach could ultimately bring neighbouring countries fully into the internal market and other relevant EU policies."1

The ultimate perspective envisaged was not membership, but full economic integration in the single market, without "shared institutions". Thus, when the ENP (European Neighbourhood Policy) was launched in 2003/2004 the basic idea was of an eventual ultimate extension of the model of the EEA (European Economic Area, explicitly recalled as a reference model by Romano Prodi in 2002), to the countries that would become EU neighbours as a consequence of the May 2004 enlargement, but with some differentiation. To the new neighbours (for a variety of reasons, both internal and external to the EU) actual prospect of membership could not be offered. ENP would have given to the neighbours some and, possibly, in perspective, all the economic advantages of membership without actual membership ("everything but institutions"), using the same kind of mechanisms and inducements as applied with success in the enlargement process. While the first motivation for elaborating the ENP was the issue of how to deal with the new Eastern European neighbours without offering the prospect of membership, in the end participation in the ENP was offered not only to the new neighbours in the East, but also to the Southern and Eastern Mediterranean countries involved in the stalled Barcelona Process, and to the South-Caucasus countries (Georgia, Azerbaijan, Armenia) that are not strictly neighbours (in the sense of having a border in common with the $\mathrm{EU}$ ), but of strategic importance to the EU (especially as a source or a transit route of hydrocarbons). ${ }^{2}$

1 Patten and Solana (2002). The memorandum by Patten and Solana is mentioned in official EU documents, however I have been unable to find its text anywhere else apart from in the site of the Lithuanian Foreign Policy Review, Internet: http://www.lfpr.lt/uploads/File/2002-10/Letter.pdf (as of July 30,2009).

2 Strictly speaking also the Mediterranean countries involved in the Barcelona process, with the exception of Morocco and Turkey (which is both a neighbour and a candidate to membership), are not EU's neighbours, in the sense of having a common territorial border with the EU. 


\section{ENP vs. Enlargement}

Just like the enlargement process the ENP is intrinsically asymmetrical. In both cases conditionality is indeed unilateral: it is exclusively for the neighbours to adapt to the EU's requirements, not vice-versa, even if some lip service is made to the "joint ownership" and to "both the ENP partner country and the EU" holding "each other accountable for living up to their mutual commitments"3. It is for the EU to establish the degree of compliance of the neighbours using "country reports", not vice-versa. As in the case of enlargement, convergence of standards and regulations is required from the neighbours towards those of the EU (not vice-versa) as an instrument for deepening economic relations, trade in particular, towards the eventual participation in an extended single market. At the same time political conditionality is prominent. ${ }^{4}$ In reality political and economic requirements may be intrinsically connected. The rule of law is not simply a political requirement, as the ways in which economic and contractual rights can be guaranteed, and public order upheld, have obvious economic implications; the same applies to good governance, while press freedom, for instance, is important to hold in check the economic costs of corruption. ${ }^{5}$ As in the process of enlargement, the path of convergence to the EU has to be followed through the drawing up and implementation of "action plans".6

In practice the attitudes of the EU's neighbours to ENP are mixed, and the policies of the EU towards its neighbours have been far from rigorous and coherent. In particular, the approach towards the neighbours to the South has been much laxer, with respect to the fulfillment of the political criteria, than that of the neighbours to the East. ${ }^{7}$ The reasons are obvious. The extension of democracy, rule of law and respect for human rights looks much more feasible with respect to European countries with high educational attainments such as Ukraine or Belarus than in the case of EU's Mediterranean Arab neighbours, where the practical alternative to authoritarianism could be the taking of power by extremist Islamist movements. Moreover,

3 COMmission of the European COMmunities (2007).

4 COMMISSION OF THE EUROPEAN COMMUNITIES (2004), "The privileged relationship with neighbours will build on mutual commitment to common values principally within the fields of the rule of law, good governance, the respect for human rights, including minority rights, the promotion of good neighbourly relations, and the principles of market economy and sustainable development. Commitments will also be sought to certain essential aspects of the EU's external action, including, in particular, the fight against terrorism and the proliferation of weapons of mass destruction, as well as abidance by international law and efforts to achieve conflict resolution."

5 See BUITER (2006).

6 For the character of ENP as a kind of prosecution of the enlargement activity, with analogous instruments and logical framework, see Delcour (2007).

7 See the enlightening parallel cases of Belarus and Tunisia, discussed in CHILOsI (2007). 
stemming the immigration tide from Africa through enhanced border control and repatriation agreements is a pressing concern for the EU, so the cooperation with sometimes unsavoury regimes may be essential.

\section{The EU's Political Expediency}

This elastic approach is no novelty. In general, considerations of political expediency appear to mark the effective application of EU rules and principles. For instance, concerning enlargement, the notion that Turkey fulfilled the Copenhagen Criteria ${ }^{8}$ and therefore that negotiations for accession could be started (as decided by the Brussels European Council of December 2004) looks rather far-fetched, in view of the repeated violations of human rights, in particular those of the ethnic minorities, and the continued special position of the military in the political system. ${ }^{9}$ The decision could be motivated by the idea (among others) of giving a boost to the Erdogan government, as an instance of a moderate Islamic democratic regime providing an alternative both to intransigent Islamism, and to authoritarian nationalism. Fundamental strategic considerations are not new in shaping the relation of the EU towards Turkey. ${ }^{10}$ The long path of convergence towards the EU, from the 1963 Association Agreement, the 1987 application to enter the EU, the 1995 customs union agreements, the 1999 granting of candidate status, found in the opening of accession talks in 2005 a natural progress. By starting the negotiation process for entering the Union, the EU could continue to exert the leverage it had with Turkey as a candidate for membership, which would have been blunted if, after years of waiting, negotiations had not been allowed to start. But the membership prospect is bound to ensure a powerful leverage only so long as it maintains some degree of credibility. In order to maintain credibility the procedure has to progress. If in due course it becomes clear that it leads to nothing (as could well be eventually the case with Turkey) then leverage is compromised or lost. At the same time leverage is obviously lost, or at

8 However only "sufficiently"; it must be noted that the "sufficiently" adverb was not present in the wording of the requirements for starting negotiations of the December 2002 Copenhagen European Council: "If the EuropeanCouncil in December 2004, on the basis of a report and a recommendation from the Commission, decides that Turkey fulfils the Copenhagen political criteria, the European Union will open accession negotiations with Turkey without delay."

9 For a recent consideration of these issues see Turkey 2008 Progress Report (COMMISSION OF THE EuroPEAN COMMUNITIES 2008).

10 In the past the relations between the EU (or rather, at the time, the European Economic Community) and Turkey could have been influenced by the contribution that Turkey was making towards the defence of the West in times of Cold War. The early stipulation of an Association Agreement, in 1963, could be seen in this light. 
least much attenuated, once a country has been admitted into the Union, as then EU's collective leverage on any single member mainly relies on the internal political dynamics of the EU and on the desire of any one member not to become unduly isolated inside the Union (aside at least from the period covered by the special admission conditions, such as the cooperation and verification mechanism in the case of Romania and Bulgaria ${ }^{11}$ ). Thus both admission and refusal may spoil EU's leverage, while the membership game, and its credibility, is bound to produce obvious externalities on other potential applicants. The fact that up to now all the countries that have been explicitly considered as actual candidates have eventually been admitted in a reasonable time span creates incentives to comply with the requirements of membership. But if this changes, the leverage provided by the process of accession may be greatly diminished. At the same time any candidate country presents different issues both of an economic and of a political nature, and its specific relations with the EU are also shaped by the internal dynamics of the EU itself, especially with respect to the support a neighbour can enjoy inside the EU. For instance the admission of Cyprus in 2004, with its gigantic unresolved issue of partition, could happen only because of the strong support of Greece, ready to veto any other prospective enlargement if Cyprus were excluded.

\section{The Neighbours and ENP}

Turning to neighbours, their attitudes to ENP have been various ${ }^{12}$. In particular Russia at once refused the ENP's asymmetric approach, out of selfawareness for its great power status, and in its subsequent relations with the EU Russia has tried to minimize the political aspect and associated requirements, and to underline "equality between partners and mutual respect of interests". ${ }^{13}$ In general one may expect the EU's leverage to be less the greater the consumer surplus the EU is able to derive from the relationship with the neighbour, and the greater the damage any disruption of economic relations could have for EU's economies. Thus, the greater the energy content of trade, the lower is the political leverage of the EU (espe-

11 See the website of the EC and the documents linked from there. Internet: http://ec.europa.eu/dgs/secretariat general/cvm/progress_reports_en.htm (as of July 30, 2009).

12 For a graphic summary of those different attitudes see EMERSON, NOUTCHEVA and POPESCU (2007).

13 EU-Russian Roadmaps 2005, quoted in Delcour (2007). However the "Strategic partnership" and the "Common Economic Space", the framework elaborated between EU and Russia in 2003, does not seem to differ in practical economic terms from the ENP approach actually followed with respect to Ukraine, as a continuation of the previous Partnership and Cooperation agreements (see Delcour 2007). Analogous considerations relate to other aspects of policy such as migration, and border management issues, or justice and home affairs. 
cially whenever the price of energy is high and/or its supply is constrained) and the greater may be the leverage of the neighbours over EU member states. This may help to explain why neighbours such as Russia and Algeria are rather cool and restrained in their relations with the EU, not to speak of Libya. ${ }^{14}$ At the same time, whenever the bulk of exports to the EU consists of raw materials and energy products rather than of manufactured or agricultural goods, the adoption of EU's rules and standards may be of less relevance for export potential.

\section{ENP vs. Enlargement}

The more recent developments in ENP policy have stressed its articulation, with the aim of deepening the relationships with the more compliant neighbours. ${ }^{15}$ At the same time the appearance of asymmetry in the relation with neighbours has been somewhat diluted, more in appearance rather than in substance, through the collective framework provided in particular by two multilateral initiatives including the EU and some subset of its neighbours, the Union for the Mediterranean and the Eastern Partnership. The dilution appears to be more apparent than substantial. The two partnerships appear more an instance of competing show-business, involving a claim to EU resources on behalf of pet neighbours by two subsets of differently geographically placed EU's states, rather than anything really substantial. They could have some value as an exercise for inducing the neighbouring countries to collaborate and interact, such as the Arab Mediterranean countries among themselves and with Israel. The origin of the Mediterranean Partnership lies with the launching of the Barcelona Process in 1995 after the Oslo Accords, but subsequently, however, the Israeli-Palestinian peace process has stalled. The Union for the Mediterranean (originally dubbed more ambitiously, and rather ambiguously, Mediterranean Union) began as an electoral stunt by French President Sarkozy and appears to have become in the end a simple renaming of the Mediterranean Partnership of the Barcelona process, destined to remain ineffectual like its predecessor. The same destiny may hold for its Eastern counterpart. The flop of its inaugural session the 7 May 2009 does not bode very well for its actual relevance.

14 For the lack of conditionality leverage in EU's relations to Russia, see DELCOUR (2007).

15 "ENP Plus"; EMERSON, NOUTCHEVA and POPESCU (2007). But the innovation appears to be mainly terminological, since there is nothing in the new concept (in particular the differentiated approach) that was not implicit in the original formulation of the ENP, as synthesized in the quote above from PATTEN and SOLANA's memorandum. 
On the whole the objective of the ENP to act as an adequate substitute for the enlargement process has been to some extent frustrated by the lower incentive potential of a scheme excluding enlargement. This problem could be to some extent overcome if the objective of ensuring to the neighbours all the advantages of membership, "but the institutions", were really pursued. But this cannot be really the case. First of all the second liberty, that of movement of people, is out of the question: given the difference in income and living standards between the EU and its neighbours, and taking into account their demography, such a freedom would easily lead to enhanced migratory movements towards the EU, with highly destabilizing potential. Second, the internal dynamics of the EU, and the unanimity vote in major budgetary decisions, leads to an allocation of financial resources that privileges members over non-members. This can be perceived at once through a cursory glance at the present financial perspective 2007-2013: the resources earmarked for the neighbours are of an order of magnitude lower than the resources dedicated to the internal cohesion policy, or to those for the Common Agricultural Policy. ${ }^{16}$ Overall, the net contributions from the European budget towards the poorer (or previously poorer, such as Ireland) members are much higher than those towards the neighbours. If the neighbours were to become members there is a good chance that any of them, with the exception of Israel, would become net recipients, according to the present EU rules and conventions, and the present net recipients would soon enough become net contributors. Analogous considerations relate to trade and access to the internal market: $;{ }^{17}$ besides the issue of barriers to agricultural imports there are those concerning sensitive sectors and antidumping measures. ${ }^{18}$ All these limitations would cease with admission to the EU, but are compatible with ENP status. The best help the EU may offer to its poorer neighbours (as well as to itself) could be to abolish all these restrictions, asking at the same time for reciprocity. In the end membership matters quite a lot, notwithstanding the ENP the potentialities of which in practice cannot be the same as those of membership, at least under the present rules and circumstances.

16 For a detailed presentation of the relevant financial data see $\mathrm{CHLOSI}_{2}$ 2007. The clout provided by being inside rather than outside the Union is made evident by the much better treatment in terms of net contributions from the EU budget obtained in 2005 by the 4 net beneficiaries of the 15 members Union, than by the poorer new members of 2004 , as the financial assistance of 2005 was decided before enlargement, and thus it was the outcome of the internal power structure of the EU of which the future poor members were no part.

17 For more on this point see CHILOSI (2007).

18 For a critical consideration of EU's antidumping procedures see EGGERT (2006). 


\section{Barriers to Enlargement}

\subsection{External}

However, further enlargement, whatever the possible merits of the neighbours, or the extent of their convergence process, may be seen to be barred both by internal as well as by external considerations. The latter refer, first of all, to the still wide cultural and institutional chasm between the EU and the Arab countries of the Southern and Eastern rim of the Mediterranean. They are outside the scope of EU membership as stated in Article 49 of the Treaties, because they are geographically as well as (arguably) culturally non-European. What is culturally European on the other hand could well be disputed (remember the discussions surrounding the aborted European Constitution), and there is the strong influence that European culture, whatever its definition, has had elsewhere, and in particular on Europe's periphery. One could well argue that the clearest embodiment of present European culture lies in the Copenhagen principles, so that if a country wholeheartedly, rather than simply instrumentally (in order to get into the EU) embraces those principles it can be considered culturally as a part of Europe. ${ }^{19}$ At the same time further possible Eastern enlargements are encroaching in the self-proclaimed sphere of interest ("near abroad") of a newly self-assertive Russia, from which a great deal of the energy for the EU originates. The possibility of "provoking" Russia by pushing the borders of the EU to include former USSR countries makes some, at least, of the "old" European countries rather cagy. Ukraine and Moldova are certainly European, thus on the basis of Article 49 they are potential candidate countries, and have already expressed their interest in entering the EU. However, unlike the Balkan countries that are not yet candidates, they are not explicitly recognized even as potential candidates, and just have neighbourhood status, together with Belarus, another unambiguously European country. The preoccupation of not antagonizing Russia by offering Ukraine some kind of membership prospect was prominent in the preparation and deliverance of the recent (July 2008) association agreement. ${ }^{20}$ In the Balkans no such prob-

19 Of course many European countries even in the recent past would have not lived up to those principles and would have appeared closer in political culture to some contemporary authoritarian quasi-democracy, or populist regimes, of the periphery. As to the geographical requirement, this is taken with some degree of elasticity. For instance Cyprus is geographically an Asian island, and the bulk of Turkish territory lies in Asia.

20 See EURACTIV (2008). Russia has only to gain if membership or association with EU brings about greater stability and prosperity to its immediate neighbours, even if in the short run there could be some trade diversion to its disadvantage (which could be however compensated by enhanced opportunities for trade in case of EU membership really enhancing their prosperity). Moreover the EU principle of the respect for minority rights may be helpful for guaranteeing the respect of the human rights of Russian minor- 
lems exist, but there further political issues complicate the concrete possibility of enlargement (such as for instance the Kosovo issue). For the countries of former Yugoslavia, with the possible exception of Croatia, as well as for the further East European neighbours, the wide disparity in economic levels presents an additional obstacle to membership, whatever the actual proclaimed status, candidate, non candidate, or potential candidate.

\subsection{Internal}

Aside from the external obstacles there are those that are internal to the EU. Enlargement requires unanimity. The wider the membership, the more complex the internal decisional process, the more cumbersome the political and institutional organization of the institutional proceedings and the more difficult the attainment of the unanimity requirement. Moreover increasing the number of members through enlargement may plausibly be seen to render the application of existing decision rules more and more awkward, negatively affecting the decision-making capability of the Union. ${ }^{21}$ The more, and more heterogeneous, the members, the higher the probability that the requirement of unanimity may lead to disruptive strategic behavior. ${ }^{22}$ In this the Lisbon Treaty (like the aborted Constitutional Treaty) does not help, since the most significant decisions (such as those relating to the budget, enlargement, and association ${ }^{23}$ ) maintain the unanimity requirement. In the "Consolidated versions of the Treaty on European Union and

ities in Russia's neighbouring countries. However political choices are not always rationally motivated, and there is the dimension of the quest for power and influence for its own sake that has to be taken into consideration. Dominance, aside from its possible favourable economic consequences, has always been an objective in itself in history. A more specific consideration refers to the control of the routes through which energy is brought to the European markets, with some implications for Russia's exertion of market power.

21 On the other hand it appears that, contrary to what it may have been feared, enlargement has not impacted negatively on the decisional power of the Commission in current affairs (see KURPAS, GRøN and KACZYNSKI 2008).

22 The drive towards strategic behavior, aimed at appropriating higher shares of aggregate collective surplus than under a "fair" distribution, may itself not only be a function of the number of countries with blocking decisional power, but also of their size distribution. For instance smaller countries could have either a greater or a smaller propensity towards strategic behavior and reckless exertion of their bargaining power. On the one hand the advantage to be reaped in terms of per capita surplus could be higher at a lower cost for the other members, and this could increase their bargaining power (this consideration could contribute to explain why for instance in the last financial perspective Ireland was able to receive the treatment of a poor country still deserving assistance, in the sense of continuing to be a net beneficiary of the UE budget). On the other, the negative consequences of blocking decisions could be higher the smaller a country and its internal market. Moreover the smaller a country the smaller could be the bargaining skills of its representatives, since they are chosen from a smaller set of eligible citizens. Of course the outcome of a bargaining process would depend very much on its specific circumstances and on the kind of decisions that have to be taken.

23 Because association agreements include matters that pertain to the second pillar, of Foreign and Security Policy, where unanimity is required. 
the Treaty on the Functioning of the European Union", incorporating the provisions of the Lisbon Treaty, unanimity decisions are mentioned about 120 times in total, and concern various subjects, deemed of particular relevance for the functioning of the Union, and for the fundamental interests of the constituent states. ${ }^{24}$ Concretely however, there seems to be little prospect of a reform abolishing unanimity to succeed, whatever the consequences for the functioning of the EU. In this respect the EU appears to be sunk in an institutional trap, the deliverance from which is not in sight. It is a classical Catch-22 situation: the proper functioning and further development of a $27+$ members Union may be incompatible with unanimity, but in order to abolish unanimity an unanimous decision plus unanimous ratification is required. ${ }^{25}$ One may remind those who may be upset by their country being deprived of its veto power that most international organizations founded on international treaties do not require unanimity for reforming their constituent treaties, ${ }^{26}$ while in the EU unanimity plus ratification by the member countries, according to their national procedures, is required for those provisions that are considered to imply a modification of the treaties. This could in practice be of great hindrance to further enlargements (and not only in the controversial case of Turkey).

\section{$7 \quad$ ENP and Association Agreements as a Second Best}

Thus, until there is an unlikely far-reaching internal reform of the Union abolishing unanimity, a more feasible way of integrating the neighbours remains the road of association agreements. As a matter of principle the extent of association could be increased so as to be tantamount to member-

24 See EUROPEAN UNION (2008). The figure is obtained by making a simple search with the root "unanim".

25 For a discussion of the obstacles that the unanimity requirement presents for the functioning of the EU, and some reform proposals, see EHLERMAN and MÉNY (2000). However the path towards abolition of unanimity and increasing the supernational character of the Union appears to be blocked for the time being, aside by the obvious political difficulties, by the recent decision of the German Constitutional Court. The latter has posed on the European agenda the further difficult issue of the quite different citizens' representation in the European parliament, inversely proportional to the demographic size of the country concerned. Another connected issue is the extent that smaller countries enjoy a representation in European institutions which is out of proportion with their size (considering in particular the unanimity requirement for the most important decisions). As a consequence it would pay for a state, in terms of representation inside the EU institutions, to split into different countries, and any state aggregation would be penalized. what appears rather perverse in terms of incentives.

26 This is stressed by EHLERMAN and MÉNY (2000): "The practice of international organisations shows that in the majority of cases the founding charter is subject to an amendment procedure which dispenses with the unanimity principle. For instance, the treaties establishing the United Nations Organization, the World Trade Organization (WTO), the International Labour Organization (ILO) and the World Health Organization (WHO) in principle require a two-thirds majority of Member States for their amendment." 
ship, in its economic consequences at least. ${ }^{27}$ To achieve this is a problem of political feasibility rather than of institutional impossibility. At the same time there are good reasons for decoupling to some extent market integration, economic assistance, and the political aspects of ENP. The first reason is that enlargement of the internal market is in the fundamental interest of the EU (as distinct from that of some of its vested interests and pressure groups). The second is that market integration can be a subtle vehicle for cultural influence and political assimilation (one may be reminded the historical classical example of Zollverein). Ultimately it could turn out to be a more effective political instrument than explicit political conditionality as a tool of "soft imperialism" ${ }^{28}$ At the same time, in case of extreme need the suspension of market access can turn out to be a powerful instrument of political leverage. Market integration could depend on the extent neighbours are prepared to conform to the rules of the single market and adapt to the relevant part of the acquis, and the extent to which they are able to adopt the institutions, such as the rule of law, that are indispensable for the functioning of a modern economy, deeply integrated with that of the EU. On the other hand market integration is one thing, aid another. Assistance, of the sort the EU confers on its needier members, may be made strictly dependent on adherence to the far-reaching political conditions formulated in Art. 2 of the Treaty of Lisbon, and in the Copenhagen criteria. If the political requirements are adhered to in full and the basic reason for not admitting a possible applicant lies in the internal dynamics of the European Union, there is no reason why assistance should not be the same as in case of membership. But the present time does not seem ripe for a reduction in the blocking power of the states that are members of the Union, nor for increasing the extent of the aid to the countries that are outside the Union so as to make their status in this regard substantially analogous to that of members.

As to the economic-institutional aspects of ENP, every neighbour of the Union is a further neighbour of somebody else. Full participation in the single market or even a more limited participation in a customs union (such as in the case of Turkey) can represent an hindrance to the integration of a neighbour with its neighbours further away. This may not represent a problem if the opportunities for trade and integration with the further neighbours are limited (such for instance for the countries of North Africa as a

27 Association agreements too require unanimity by EU members, plus ratification, but this is a somewhat less controversial issue, since association leads to a less important and permanent status than membership. In this case too there could be standoffs, such as in the case of the association agreement between the EU and Slovenia (signed in 1996), which was delayed by a controversy between Italy and Slovenia.

28 For the notion of soft imperialism, through which the West tries to make of the Rest a replica of itself, and of ENP as an instance of it, see CHLOSI (2007). 
whole with respect to their southern neighbours). It represents an issue for countries, such as EU's Eastern neighbours (the Ukraine in particular), that are close to an economically important market (Russia). In this case a customs union with the EU could represent an obstacle for taking advantage of the economic benefits of proximity, and a source of trade diversion. This would be not be the case if Russia were to enter in a free trade agreement with the Union. But it seems that Russia is instead poised to create an autonomous economic space by building a separate customs union with some subset of CIS members. Then instead of full integration with the Union, a free trade agreement with both economic areas could perhaps be more to the advantage of our Eastern neighbours, even if managing the rules of origin can be onerous and would reduce the extent of economic integration. ${ }^{29}$ This kind of arrangement could also have some political merits for a country divided in its attitudes such as Ukraine, but may not be politically acceptable to Russia, owing to its present propensity to exert pressure towards the countries of its "near abroad" (Ukraine in particular) to draw them more strictly into its economic and political orbit.

\section{Prospects of Fundamental Institutional Reform}

Eventually, if and when the time is ripe, the potentially paralyzing power of any single state to block EU's most important decisions could be abolished by dispensing with the unanimity requirements altogether, tilting the balance of the architecture of the Union decisively in a supranational direction. In a sense, enhanced supranational powers are the logical consequence of continuous increasing, through enlargement, the number of member states, if the objective is to preserve a functioning EU, unhindered by the "liberum veto"..$^{30}$ The abolition of the unanimity requirement could favour enlargement on two counts: first by reducing the obstacles towards coopting new members, and second by reducing the probability that any new member would seriously disrupt the working of the Union, thus reducing the risk of its acceptance. The latter consideration would be even stronger if any troublesome member were concretely eligible for expulsion rather than simply to suspension, as is presently the case (for which the unanimity of the other

29 See SHUMYLo (2006).

30 One may be reminded of how the "liberum veto" contributed to the eventual downfall of the Polish-Lithuanian Commonwealth. If recklessly used it could eventually become the bane of that other peculiar multinational European Commonwealth, the European Union. Until now the EU has always been able, in the end, to weather the storms, and overcome the setbacks engendered in turn by its most troublesome members, steadily progressing in developing its institutions, integrating and enlarging. Unfortunately this does not need to continue in the future if the institutions are not able to adapt to numerosity and size. 
members is anyway required, with all the implied difficulties) ${ }^{31}$ On the other hand suspension could amount to de facto expulsion if all the rights relating to membership of the offending member were to be suspended. At that point the most plausible path for the suspended member would to exit from the Union according to the provision of art. 50 of the Lisbon Treaty, in order to be released from its persistent obligations towards the Union. On the other hand the suspension of a member, and the virtual expulsion if all the rights of a member were suspended, could be politically traumatic. It could be argued that it would be politically safer to avoid admitting a potentially troublesome member rather than risk a hazardous suspension process if and when the new member proved to be unfit for the Union. In particular in order to admit a new member safely one should be confident that not only the present government shares basic European values, but also that this is the case for the potential political alternative, in case the opposition were to become the government party. But realistically speaking there is no concrete possibility of an essential, if momentous, step, such as the abolition of unanimity, for the foreseeable future.

Eventually a possible model of EU a la carte could be adopted, building on the enhanced cooperation model, and on the precedent of derogations for some countries, introducing a kind of reduced cooperation alternative, whereby membership could be restricted to only some aspects of the Union. For instance, a country not satisfying all the political conditions, but satisfying the economic requirements, could be admitted to share the economic framework of the EU, but not take part in politically relevant decisions. This would be a status not very different from a model of enhanced association (intermediate between association and full membership), or of a member with some membership rights suspended. ${ }^{32}$ In the end the same objectives could be pursued through a suitable modulation of an enhanced ENP, such as ENP with market enlargement as far as a customs union (as with Turkey, but more inclusive: the customs union with Turkey does not include either agriculture or public procurement and is subject to antidumping protectionist measures); or participation in the single market through an enhanced free trade association with smooth and prompt mirroring of EU norms and

31 See art 7.2 of the consolidated Lisbon Treaty, which corresponds to art. 7.2 of the Treaty currently in force. Notice that point 3 of the procedure requires qualified majority, but the previous step needs unanimity.

32 The idea of introducing a more limited type of EU membership was advanced by THE ECONOMIST (2005). 
regulations, as in the EEA. ${ }^{33}$ An additional element mirroring the advantages of membership could be a degree of assistance approaching the extent of assistance the EU offers to its worse-off members. In the end this may be the most and the best that Europe can still offer to its neighbours. One should not be blind to the fact that under present circumstances this is the perspective that is de facto offered to prospective, and even actual, candidate countries such as Turkey, notwithstanding that the approximation and the deepening of economic relations in this case are officially in the framework of the preparation for accession. Even when, and if, Turkey will completely adapt, and all the chapters will be successfully closed (a perspective that at the moment seems far away ${ }^{34}$ ) one may doubt whether Turkey would ever be admitted to a EU where accession requires unanimity, as well as ratification by all the member states. Thus, while the process of accession drags on, one may presume that the leverage deriving from the ongoing accession process will be progressively eroded and eventually lost, even if in the meantime it may have been used as an ideological weapon by modernizing forces inside Turkey. Only in the case of Croatia admission appears to be concretely possible in a limited time span, as a kind of leftover of the 2004 process, if, and when the current standoff with Slovenia will end. In the end the newest application to EU membership of Iceland could be more successful, owing to its advanced developed status, its long standing democratic institutions and its membership of the European Economic Area.

33 "Tailor-made deep and comprehensive free trade agreements (DFTAs), including measures to reduce non-tariff barriers through regulatory convergence, are the keys to increased economic integration with ENP partners" (COMMISSION OF THE EUROPEAN COMMUNITIES 2007). The EEA's participation in the single market is not complete, as it excludes agriculture and fisheries (limitations that correspond for obvious reasons to the desires of Norway and Iceland rather than to those of the EU). Moreover the nature of the free trade area of the EEA implies as a matter of principle the rules of origin complication. In the case of the present EEA this does not present really a problem since the requirements are simplified and the system operates quite smoothly (ROYAL NORWEGIAN MINISTRY OF ForeIGN AFFAIRS 1995), but it may present a problem for less advanced neighbours (here participation in the future System of Pan-EuroMediterranean cumulation however could help).

34 See all the complex and difficult issues highlighted in the Turkey 2008 Progress Report by the European Commission. 


\section{References}

Buiter, WILliam (2006), Intervention on Turkey Country Economic Memorandum: Promoting Sustained Growth and Convergence with the European Union, 9 March 2006, CEPS report of event posted 27 February 2007, Internet: http://www.ceps.be/Article.php?article_id=516 (as of July 29, 2009).

Chilosi, Alberto (2007), The European Union and its Neighbours: Everything but Institutions?, The European Journal of Comparative Economics, 4 (1), pp. 25-38, Internet: http://eaces.liuc.it/18242979200701/ 182429792007040102.pdf (as of July 20, 2009).

COMMISSION OF THE EuRoPEAN COMMUNITIEs (2004), European Neighbourhood Policy Strategy Paper No. 12/5/2004, Internet: http://ec.europa.eu/ world/ENP/pdf/strategy/strategy_paper_en.pdf (as of July 1, 2009).

COMMISSION OF THE EUROPEAN COMMUNITIES (2007), Communication from the Commission: A Strong European Neighbourhood Policy No. 5/12/ 2007.

COMMISSION OF THE EUROPEAN COMMUNITIEs (2008), Turkey 2008 Progress Report No. 5/11/2008, Internet: http://eur-lex.europa.eu/LexUriServ/ LexUriServ.do?uri=SEC:2008:2699:FIN:EN:PDF (as of June 30, 2009).

Delcour, Laure (2007), Does the European Neighbourhood Policy Make a Difference? Policy Patterns and Reception in Ukraine and Russia, European Political Economy Review, Issue 7 (Summer), pp. 118-155.

ECONOMIST (2005), Meet the Neighbours, The Economist, June 23, 2005.

EGgERT, JAN (2006), Observations on the EU Anti-Dumping Regulation FTA Position for the Expert Meeting, Brussels, 11 July 2006, Internet: http://trade.ec.europa.eu/doclib/docs/2006/september/tradoc_129812. pdf (as of July 30, 2006).

Ehlermann, Claus-Dieter and Yves MÉny (eds.) (2000), Reforming the Treaties' Amendment Procedures: Second Report on the Reorganisation of the European Union Treaties, Submitted to the European Commission on 31 July 2000, Florence: Robert Schuman Centre for Advanced Studies, Internet: http://www.iue.it/RSCAS/Research/Institutions/2nd rapport_UK.pdf (as of July 1,2009).

EMERSon, Michael (ed.) (2005), Democratisation in the European Neighbourhood. Brussels: CEPS, Internet: http://shop.ceps.eu/BookDetail. php?item_id=1267 (as of July 30, 2009).

Emerson, Michael, Gergana Noutcheva and Nicu Popescu (2007), European Neighbourhood Policy Two Years on: Time Indeed for an 'ENP plus', CEPS Policy Brief No. 126/March. 
Euractiv (2008), EU Offers Ukraine Partnership, but not Membership, 23 July 2008.

EUROPEAN UNION (2002), 2421st Council meeting - General Affairs, Luxembourg, 15 April 2002.

EUROPEAN UNION (2006), Consolidated Versions of the Treaty on European Union and of the Treaty Establishing the European Community, Official Journal of the European Union, 29.12.2006.

EUROPEAN UNION (2008), Consolidated versions of the Treaty on European Union and the Treaty on the Functioning of the European Union, Official Journal of the European Union.

Kurpas, Sebastian, Caroline Grøn and Piotr Maciej Kaczynski (2008), The European Commission After Enlargement: Does more Add up to Less?, CEPS Special Report, February 2008.

Patten, Chris and Javier Solana (2002), Wider Europe 2002, letter addressed to the Brussels 30 September 2002 General Affair Council, Internet: http:/www.lfpr.lt/uploads/File/2002-10/Letter.pdf (as of July 15, 2009).

Prodi, Romano (2002), A Wider Europe-A Proximity Policy as the Key to Stability, Sixth ECSA World Conference, Jean Monnet Project, Brussels, 5/6 December 2002.

Royal Norwegian Ministry of Foreign AfFairs (1995), Norway, The European Economic Area (EEA) and the EU's Internal Market, October 1995.

Senior Nello, Susan (2009), The European Union: Economics, Policies and History, London: McGraw-Hill.

ShUMYLO, OlGa (2006), Ukraine and the European Neighbourhood Policy. Ensuring the Free Movement of Goods and Services, CEPS Working Document No. 240. 
Autoren - Authors

Wolfgang Ramsteck

Friedrich-Alexander-Universität Erlangen-Nürnberg

Rechts- und Wirtschaftswissenschaftliche Fakultät

Lehrstuhl für Auslandswissenschaft

Findelgasse $7 / 9$

D-90402 Nürnberg

Deutschland

wolfgang.ramsteck@wiso.uni-erlangen.de

Prof. Alberto Chilosi

Department of Economics

University of Pisa

Via Serafini, 3

IT-56126 Pisa

Italien

chilosi@sp.unipi.it

\section{Valentin Zahrnt}

Dr. rer. pol. lic. oec. HSG

Zahrnt Consulting \& Communication

European Centre for International Political Economy (ECIPE)

Rue Belliard 4-6

B-1040 Brussels

Belgien

valentin.zahrnt@ecipe.org

\section{Dr. Chukwuma Agu}

African Institute for Applied Economics

128 Park Avenue

GRA, Enugu

Nigerien

shookslife@yahoo.com 